\title{
Decrease in the Degree of Lymphosplenomegaly and in the Serum IFN- $\gamma$ Concentration but not in the Production of IgG and Anti-DNA Antibody in BXSB Mice Treated with Anti-IL-2 Receptor $\beta$ Antibody
}

\author{
Mikio TAKeshima', Yoshiko Habu ${ }^{3}$, Hoshio Hiraide ${ }^{2}$ and Shuhji SeKI ${ }^{3}$ \\ 'Medical Division, National Defense Academy, Yokosuka, Kanagawa 239-8686, Japan \\ ${ }^{2}$ Division of Basic Traumatology, National Defense Medical College Research Institute, Tokorozawa, Saitama 359-8513, Japan \\ ${ }^{3}$ Department of Microbiology, National Defense Medical College, Tokorozawa Saitama 359-8513, Japan
}

(Received 27 February 2002; and accepted 25 March 2002)

\begin{abstract}
In autoimmune Male BXSB mice, IL-2 receptor $\beta(\mathrm{CD} 122)^{+} \mathrm{CD} 4^{+} \mathrm{T}$ cells with internediate TCR are known to produce lymphosplenomegaly. The aim of the present study is to clarify whether or not these $\mathrm{CD} 4^{+} \mathrm{T}$ cells are involved in the pathogenesis of the disease. Male BXSB mice were injected with anti-CD122 $\mathrm{Ab}$ (antibody) weekly from 8 to 13 weeks of age and mice were examined at 18 weeks of age. In addition to the inhibition of the lymphosplenomegaly, the number of lymphocytes in the spleen and liver were greatly reduced in Ab-treated BXSB mice by the decrease of $\mathrm{CD} 122^{\circ} \mathrm{CD} 4^{+} \mathrm{T}$ cells. Furthermore, the serum IFN $-\gamma$ levels of Ab-treated BXSB mice decreased and mononuclear cell-infiltration in the liver as well as mesangeal lesions in the glomeruli also decreased. Lymphocytes isolated from the liver of Ab-treated BXSB mice showed a smaller natural killer (NK) NK-activity than did those of the control BXSB mice. However, the elevated serum IgG and anti-DNA $\mathrm{Ab}$ levels did not significantly differ between the two groups. Our findings suggest that $\mathrm{CD} 122^{+} \mathrm{CD} 4^{+} \mathrm{T}$ cells with intermediate TCR with NK activity are partly related to the pathogenesis of lupus like disease in BXSB mice, however, they do not play a substantial role in auto-antibody production.
\end{abstract}

Male BXSB mice develop an autoimmune lupuslike disease accompanied by moderate lymphadenopathy and autoantibody production due to the presence of a gene on the $Y$ chromosome (Yaa gene) (3, 24). We recently reported that $\mathrm{CD} 122^{+} \mathrm{CD} 4^{+} \mathrm{T}$ cells with intermediate TCR were found to numerically increased in every lymphoid organ in aged male BXSB mice (24). These T cells showed a different $\mathrm{T}$ cell receptor repertoire from that of regular $\mathrm{T}$ cells with high TCR and these T cells in the liver of aged male BXSB mice possess a potent NK activity (24).

Correspondence to: Shuhji Seki, M.D.

Department of Microbiology, National Defense Medical College, Tokorozawa Saitama 359-8513, Japan

TEL: 042-995-1541 FAX: 042-996-5194

e-mail: btraums@res.ndmc.ac.jp
In normal C57BL/6 mice (NK1.1 positive strain), intermediate TCR cells are composed of CD122 ${ }^{+} \mathrm{NK}$ $1.1^{+} \mathrm{T}$ cells and $\mathrm{CD} 122^{+} \mathrm{NK} 1.1^{-} \mathrm{T}$ cells $(20,21)$. CD122 ${ }^{+} \mathrm{NK} 1.1^{+} \mathrm{T}$ cells are either $\mathrm{CD}^{+}$or $\mathrm{CD}^{-}$ CD8 while CD $122^{+} \mathrm{NK} 1.1^{\prime} \mathrm{T}$ cells are mainly $\mathrm{CD} 8^{+}$ and both are abundant in the liver. CD $122^{+} \mathrm{NK} 1.1^{1} \mathrm{~T}$ cells specifically use either $\mathrm{V} \alpha 14-\mathrm{J} \alpha 281 / \mathrm{V} \beta 7$ or $V \alpha 14-\mathrm{J} \alpha 281 / \mathrm{V} \beta 8$ TCR gene products for their TCR $(7,15,20,21)$. This population can also be identified in mice of NK1.1 negative strain mice by V $\alpha 14-J \alpha 281$ TCR gene mRNA because only these cells express V $\alpha 14-\mathrm{J} \alpha 281$ TCR (20). However, since expanded $\mathrm{CD} 122^{+} \mathrm{CD} 4^{+\mathrm{T}} \mathrm{T}$ cells with intermediate TCR in BXSB mice did not use V $\alpha 14$ gene products for their TCR, they are different from either NKT cells or $\mathrm{CD} 122^{+} \mathrm{NK} 1.1^{-} \mathrm{CD}^{+} \mathrm{T}$ cells (24). In the case of autoimmune MRL 1pr/lpr mice, we indi- 
cated that intermediate TCR cells which demonstrate lymphosplenomegaly in these mice are derived from $\mathrm{CD} 122^{+} \mathrm{NK} 1.1^{-} \mathrm{CD} 8^{+} \mathrm{T}$ cells $(14,20)$. As a result, $\mathrm{CD} 122^{+} \mathrm{CD} 4^{+} \mathrm{T}$ cells in aged male BXSB mice is thus considered to be a very peculiar cell population for these mice that can not be classified into ordinary $T$ cell populations with high TCR or intermediate TCR in other strains of mice and female BXSB mice (24). In the present study, to clarify the role of the $\mathrm{CD} 122^{\circ} \mathrm{CD} 4^{*} \mathrm{~T}$ cells in the immunopathological state of BXSB mice, male $\mathrm{BXSB}$ mice were injected with anti-CD122 Ab which was previously shown to deplete $\mathrm{CD} 122^{+}$ cells for several days by a single injection into mice $(19,20)$. Our present results show that anti-CD122 $\mathrm{Ab}$ treatment of BXSB mice greatly decreased $\mathrm{CD} 122^{+} \mathrm{CD} 4^{+} \mathrm{T}$ cells, significantly reduced the serum IFN- $\gamma$ concentration and improved histopathological findings in the liver and kidney while it did not decrease the serum $\operatorname{lgG}$ and anti-DNA Ab levels.

\section{MATERIALS AND METHODS}

Mice and preparation of liver and spleen $M N C$. Male and female BXSB mice at 6 weeks of age were obtained from Nippon SLC (Hamamatsu, Japan). Mice were maintained and fed under the standard laboratory conditions. Hepatic mononuclear cells (MNC) were prepared essentially as described (20). In brief, the liver was passed through a stainless steel mesh, and the resulting dissociated cells were suspended in HBSS, washed, resuspended in an isotonic 33\% Percoll solution (Sigma) containing heparin $(100 \mathrm{U} / \mathrm{mL})$, and centrifuged at $500 \times g$ for $15 \mathrm{~min}$ at room temperature. The resulting pellet was resuspended in a red blood cell lysis solution and then washed twice in RPMI 1640 medium supplemented with $5 \%$ FCS. Splenocytes were passed through a 200 gauge stainless steel mesh and were treated with a red blood cell lysis solution and were washed twice in 5\% FBS RPMI 1640.

Flow cytometric analysis. The surface phenotypes of liver MNC were characterized by two-color or threecolor flow cytometric analysis. An FITC-conjugated hamster $\mathrm{mAb}$ to mouse TCR $\alpha \beta$ (H57-597, IgG) and a PE-conjugated mouse mAb to IL-2 receptor $\beta$ $(\mathrm{CD} 122)(\mathrm{TM} \beta 1)(18)$ were obtained from PharMingen (San Diego, CA). Before staining with Abs, the MNC were incubated for $10 \mathrm{~min}$ with Fc-blocker (2.4 G2, PharMingen) to prevent nonspecific binding. Flow cytometry was performed with EPICS XL (Coulter, Miami, FL).
In vivo cell depletion. $200 \mu \mathrm{g}$ of monoclonal $\mathrm{Ab}$ to mouse IL-2 receptor $\beta$ (TM $\beta 1$ ) were injected into the mice once a week from 8 weeks of age until 13 weeks of age. TM $\beta 1$ hybridoma was grown in the Department of Microbiology, National Defense Medical College. We previously showed that a single $i v$. injection of TM $\beta 1$ Ab deplete IL-2 receptor $\beta^{+}$cells for approximately a week (19).

Cytotoxicity assay. NK cell-sensitive YAC-1 lymphoma cells were used as target cells. Target cells ( 3 $\times 10^{6}$ ) were labeled for $60 \mathrm{~min}$ at $37^{\circ} \mathrm{C}$ with 100 $\mu \mathrm{Ci}$ of $\mathrm{Na}_{2}{ }^{31} \mathrm{CrO}_{4}$ in $500 \mu \mathrm{L}$ of RPMI 1640 supplemented with $10 \%$ FCS. They were then washed three times with medium alone and subjected to a cytotoxicity assay. The labeled targets $\left(1 \times 10^{4}\right.$ cells per well) were incubated with liver or spleen MNC for $4 \mathrm{~h}$ at $37^{\circ} \mathrm{C}$ in 96 -well round-bottomed microtiter plates containing RPMI 1640 (total volume of $200 \mu \mathrm{L}$ ). The plates were then centrifuged, and the resulting supernatants were harvested and their omit radioactivity was determined with a gamma counter. Cytotoxicity was calculated as the percentage of released radioactivity after correcting for spontaneous release, which was $<15 \%$ of the maximal release.

Measurement of serum IFN- $\gamma, \operatorname{IgG}$ and singlestranded anti-DNA $A b$. The serum concentration of IFN- $\gamma$ was measured by an ELISA kit (OptEIA ${ }^{\mathrm{TM}}$ ) (PharMingen, San Diego, CA). The serum IgG levels were measured by mouse IgG ELISA kit (Bethyl Laboratory, Montgomery, TX) and single-stranded anti-DNA Ab were also measured by an ELISA kit (MBL, Nagoya, Japan).

Statistical analysis. Differences among groups were analyzed by the Mann-Whitney $U$ test with StatView software. A $P$ value of $<0.05$ was considered statistically significant.

\section{RESULTS}

Reduction in the degree of lymphosplenomegaly, the total number of the liver and spleen MNC in the TM $\beta 1$ Ab treated $B X S B$ mice

After treating the male BXSB mice once a week with TM $\beta 1 \mathrm{Ab}$ from 8 weeks of age to 13 weeks of age, the mice were then examined at 18 weeks of age. The weight of the spleens and the size of lymph nodes in Ab-treated BXSB mice were much smaller than that of the control BXSB mice (Table 1). The total number of splenocytes and liver MNC of the Ab-treated mice were also much smaller than those 
of control mice (Table 1).

Reduction in the number of $\mathrm{CD} 122^{+}$intermediate TCR cells in the liver and spleen MNC of antiCD122 Ab-treated BXSB mice

We recently reported the expanded $T$ cells observed in aged male BXSB mice to be unusual $\mathrm{CD} 4^{+}$ CD $122^{+}$intermediate TCR cells (24). In the liver, approximately $30 \%$ of the $\mathrm{MNC}$ were $\mathrm{CD} 4^{+} \mathrm{CD} 122^{+}$ intermediate TCR cells and $40-50 \%$ of the MNC were $B$ cells while rest of the MNC were NK cells and regular $\mathrm{T}$ cells (24). TM $\beta 1 \mathrm{Ab}$ treatment of BXSB mice greatly decreased the proportion of in- termediate TCR cells in T cells both in the liver and spleen (Fig. 1).

Decrease in the serum IFN-7 levels and NK activity of liver MNC but not in the serum IgG and singlestranded anti-DNA Ab levels in the Ab-treated mice The serum IFN-y levels in Ab-treated BXSB mice were significantly lower than those in the control BXSB mice (Fig. 2). However, the serum IFN- $\gamma$ levels of age-matched B6 mice or female BXSB mice were undetectable (not shown). The NK activity in the liver $\mathrm{MNC}$ of $\mathrm{TM} \beta 1 \mathrm{Ab}$ treated $\mathrm{BXSB}$ mice was significantly lower than that in the control

Table 1 Decrease in the number of liver MNC and lymphosplenomegaly of BXSB mice injected with anti-IL2Rß Ab (TMB1)

\begin{tabular}{lcc}
\hline & TM $\beta \mathrm{I}_{(\mathrm{n}=5)}$ & PBS $(\mathrm{n}=5)$ \\
\hline Weight of liver $(\mathrm{g})$ & $1.17 \pm 0.15$ & $1.50 \pm 0.03$ \\
Number of liver $\mathrm{MNC}\left(\times 10^{6}\right)$ & $2.6 \pm 0.2^{* *}$ & $8.5 \pm 1.9$ \\
Weight of spleen $(\mathrm{mg})$ & $85 \pm 15^{* *}$ & $570 \pm 5$ \\
Number of spleen MNC $\left(\times 10^{8}\right)$ & $1.2 \pm 0.2^{*}$ & $3.9 \pm 0.4$ \\
Major axis of the inguinal lymph node $(\mathrm{mm})$ & $3.0 \pm 0.4^{*}$ & $6.5 \pm 0.9$ \\
\hline
\end{tabular}

$* P<0.05$

$*{ }^{*} P<0.01$

$\operatorname{TM} \beta 1$

Liver

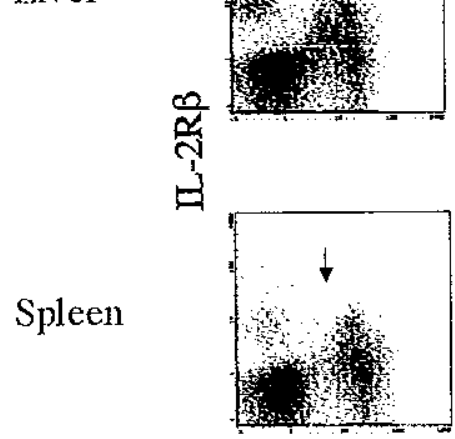

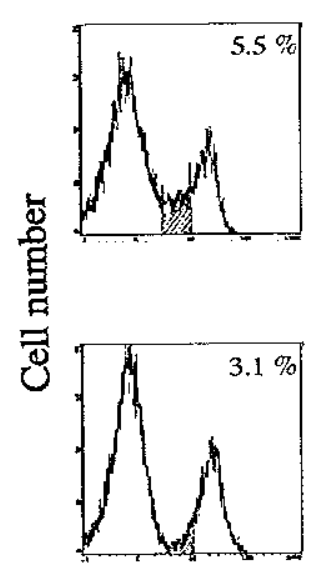

PBS
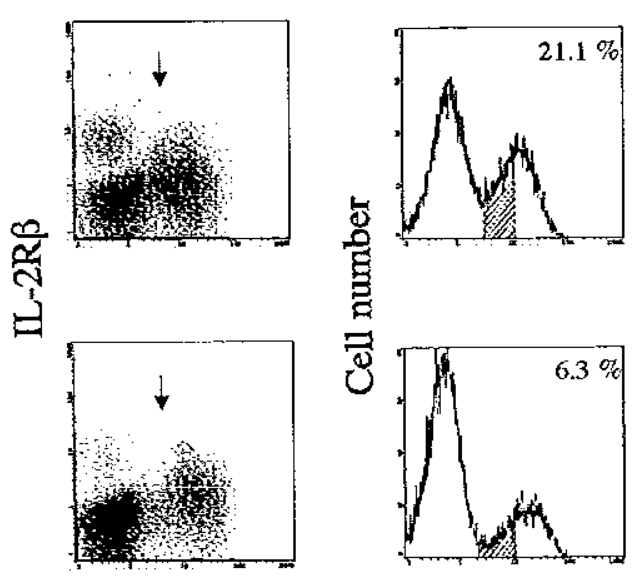

\section{$\alpha \beta T C R$}

Fig. 1 Proportional decrease in the number of IL-2R $\beta^{+}$intermediate TCR cells in the liver and spleen in 18-week old male BXSB mice injected with $\mathrm{TM} \beta 1 \mathrm{Ab}$ (PBS injected mice as a control).

The arrows in two color profiles and the highlighted section of the single histograms of $\alpha \beta$ TCR indicate IL-2R $\beta^{+}$intermediate TCR cells. 


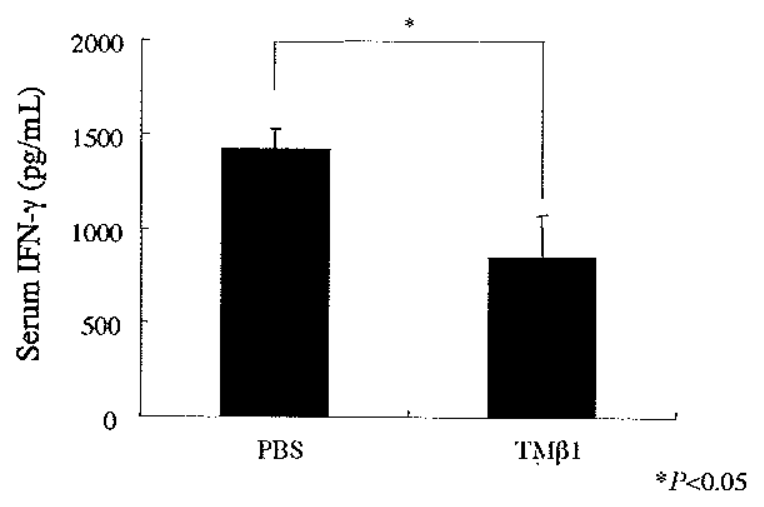

Fig. 2 Decrease in the serum IFN- $\gamma$ levels in the $\mathrm{TM} \beta 1 \mathrm{Ab}$ treated male BXSB mice.

The data are the means \pm S.E.S from 6 mice of either the $\mathrm{Ab}$-injected group or the PBS-injected group.

BXSB mice despite the fact that the proportion of NK cells in the liver MNC of Ab treated mice and control mice did not differ significantly (Table 2), thus suggesting that the decrease in the number of $\mathrm{CD}^{+} \mathrm{CD} 122^{+}$intermediate TCR cells was responsible for the reduction in the NK activity observed in the $\mathrm{Ab}$ treated $\mathrm{BXSB}$ mice. However, the $\mathrm{TM} \beta 1 \mathrm{Ab}$ treatment did not significantly inhibit the increase in the serum $\operatorname{IgG}$ and anti-DNA $\mathrm{Ab}$ levels in male BXSB mice (Fig. 3).

Histopathological findings of the liver and kidneys of anti-CD122 Ab treated mice and control BXSB mice

The livers of the 18-week-old control BXSB mice showed lymphocyte infiltration in the sinusoids, a ballooning of hepatocytes and some focal spotty necrosis of hepatocytes, whereas similar findings were rare in the anti-CD122 $\mathrm{Ab}$ treated $\mathrm{BXSB}$ mice (Fig.
$4 a, b)$. The glomeruli of the control BXSB mice also showed mononuclear cell proliferation in the glomeruli while the changes in the glomeruli of the $\mathrm{Ab}$ treated mice were less obvious (Fig. 4c, d).

\section{DISCUSSION}

In the present study, we demonstrated that the antiCD122 Ab treatment of male BXSB mice decreased the accumulation of intermediate TCR cells in the liver, spleen and lymph nodes and also reduced the $\mathrm{NK}$ activity of liver MNC. However, although the
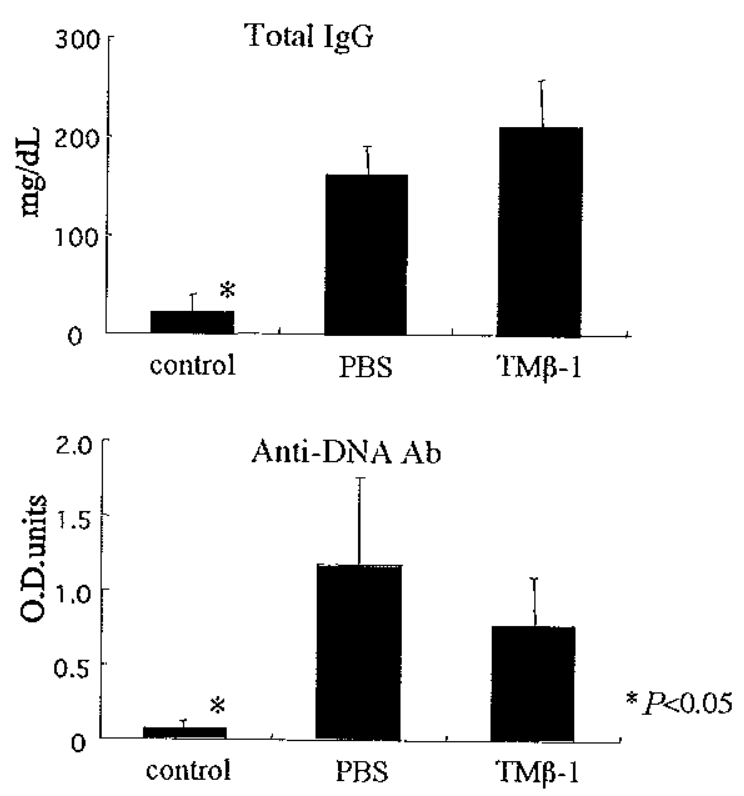

Fig. 3 Total $\operatorname{IgG}$ and anti-DNA $\mathrm{Ab}$ levels in the $\mathrm{TM} \beta 1 \mathrm{Ab}$-treated mice and PBS-injected mice.

The data are the means \pm S.E.S from 6 mice of each group.

Table 2 Inhibition of $N K$ activity in the liver MNC in BXSB mice after the injection of anti-LL2RB Ab (TMB1)

\begin{tabular}{lcccc}
\hline Treatment & MNC & $50: 1$ & $25: 1$ & $12.5: 1$ \\
\hline PBS & liver & $30.7 \pm 1.0$ & $16.2 \pm 2.2$ & $8.5 \pm 0.4$ \\
TM $\beta$ & & $14.0 \pm 3.4^{*}$ & $8.8 \pm 0.3^{*}$ & $3.6 \pm 1.9^{* *}$ \\
\hline PBS & spleen & $1.7 \pm 0.0$ & $1.6 \pm 0.4$ & $1.7 \pm 1.5$ \\
TM $\beta 1$ & & $2.2 \pm 1.6$ & $1.2 \pm 0.8$ & 0 \\
\hline
\end{tabular}

$* P<0.05$

$* * P<0.01$

Data are meau \pm S.E.S. of values from triplicate samples, Data are of tained from an experiment that was repeated three times with similar results. 

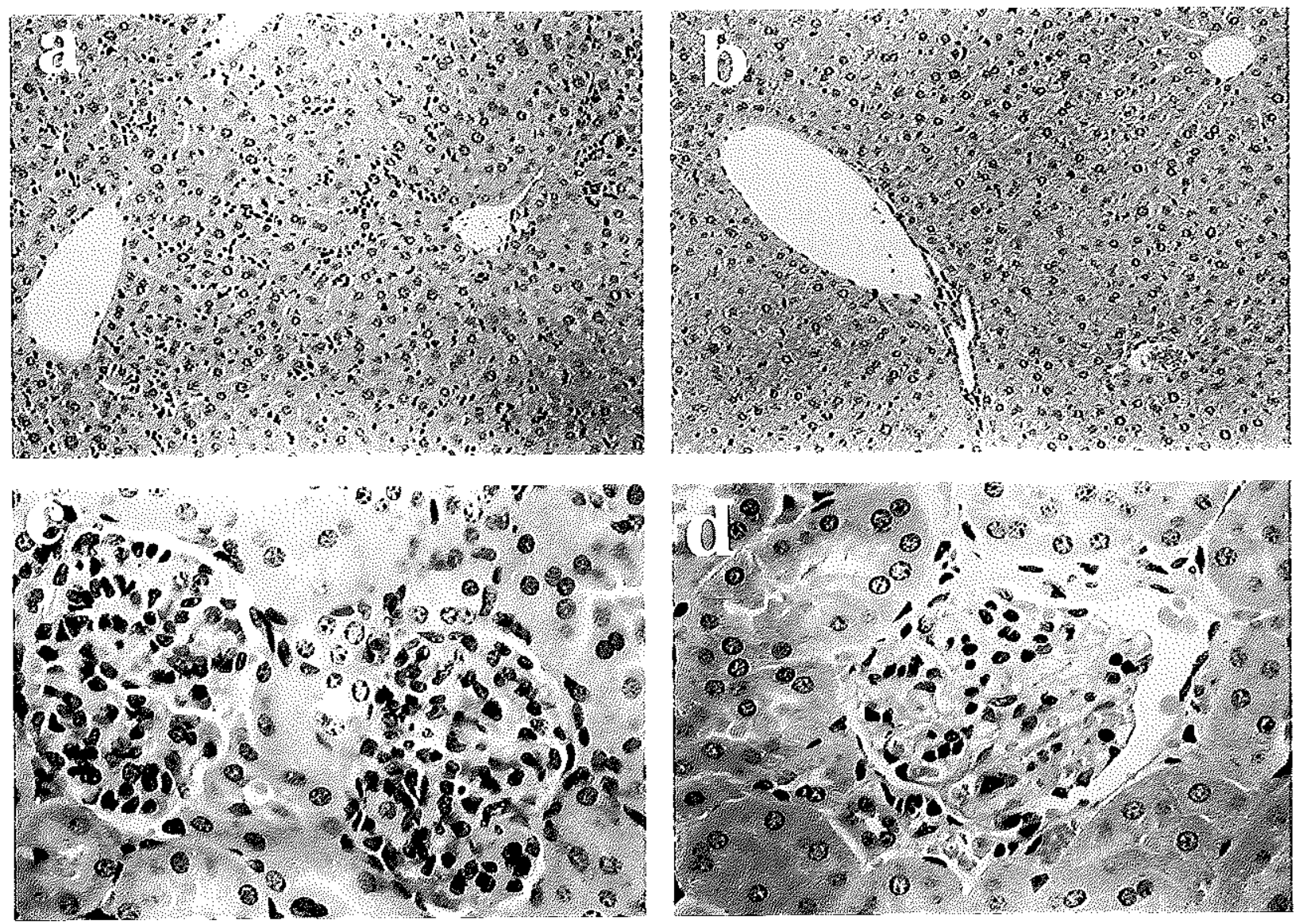

Fig. 4 Histopathological findings (hematoxylin-eosin staining) of the liver and the glomeruli of the kidney. a. liver of a PBS-treated mouse $(\times 50)$. b. liver of a TM $\beta 1$-treated mouse.

c. glomerulus of a PBS-treated mouse. $d$. glomerulus of a TM $\beta 1$-treated mouse.

$\mathrm{Ab}$ treatment also partially inhibited the increase in the serum IFN- $\gamma$ levels and also improved mononuclear cell-infiltration in the liver and kidneys, the serum IgG and anti-DNA $\mathrm{Ab}$ levels did not significantly improve.

Previous reports indicated that $\mathrm{T}$ cells are involved in the immuno-pathogenesis of BXSB mice because the depletion of $\mathrm{CD} 4^{+} \mathrm{T}$ cells by anti- $\mathrm{CD} 4$ $\mathrm{Ab}$ significantly improved the autoimmune disease of male BXSB mice (22). However, as we previously reported that $\mathrm{CD}^{+} \mathrm{T}$ cells which expanded in male BXSB mice are suggested to be different from regular $\mathrm{CD}^{*} \mathrm{~T}$ cells because of their intermediate TCR intensity, CD122 expression and different TCR repertoire (24). We therefore used $\mathrm{TM} \beta 1 \mathrm{Ab}$ in order to decrease the number of $\mathrm{CD} 4^{+} \mathrm{CD} 122^{+} \mathrm{T}$ cells. As a result, the degree of tymphosplenomegaly was greatly inhibited.

On the other hand, IL- 4 has been suggested to play an important role in the induction of autoim- mune diseases partly because IL-4 is an essential cytokine for immunoglobulin production including auto-antibody production $(1,9)$. However, recent reports have suggested that IFN- $\gamma$ rather than IL-4 may play an important role in the induction and acceleration of disease $(12,16)$. In fact, IL-4 gene deficient male BXSB mice did not show an improvement in the disease in comparison to the intact BXSB mice (6). In addition, anti-IFN- $\gamma$ Ab or anti-IFN- $\gamma$ receptor $A b$-injected mice showed less severe symptoms in some autoimmune models of mice $(5,11)$. Consistent with these findings, the treatment of BXSB mice with TM $\beta 1 \mathrm{Ab}$ partially but significantly reduced the serum IFN- $\gamma$ levels and partially improved the histopathology of the liver and kidney in comparison to the control BXSB mice, although the IFN- $\gamma$ levels of Ab-treated BXSB mice were still much higher than those in female BXSB mice. It can be speculated that regular $\mathrm{CD}^{+} \mathrm{T}$ cells and $\mathrm{CD} 8^{+} \mathrm{T}$ cells could also be involved 
in the disease and may produce IFN- $\gamma$. As far as we know, this report demonstrated, for the first time, elevated serum IFN- $\gamma$ levels in male BXSB mice. These findings suggest that $\mathrm{CD}^{+}$intermediate TCR cells are indeed responsible for the $T$ helper 1 dominant state in BXSB mice, however, they are not largely involved in the Ig production from B cells in these mice. This is in contrast to the findings of antiCD4 Ab treatment in BXSB mice because which has been shown to significantly reduce lymphadenopathy as well as anti-DNA Ab production, thereby suggesting that regular $\mathrm{CD} 122^{-} \mathrm{CD} 4 \mathrm{~T}$ cells are required for Ig production from $\mathrm{B}$ cells.

$T$ cell receptor gene-deleted BXSB mice, namely $T$ cell deficient BXSB mice, have recentry been shown to not develop any disease including autoantibody production and glomerulonephritis, thus indicating that $\mathrm{T}$ cells are essential cellular components for the induction of the autoimmune disease (8).

Surprisingly, however, the adoptive transfer of small numbers of $\mathrm{CD} 4^{+} \mathrm{T}$ cells not only from male BXSB mice but also from female BXSB mice has been shown to induce the expansion of $T$ cells in $T$ cell receptor gene-deleted BXSB mice (8). Since male BXSB mice but not female BXSB mice have a Yaa gene, these findings suggest that the $T$ cells themselves do not have a Yaa-gene-induced intrinsic abnormality but that other cellular components, such as $B$ cells and macrophages or other tissues may be affected. In fact, the increase in the number of activated monocytes are always observed $(4,23)$ and approximately a half of the MNC in the liver, spleen and lymph nodes are B cells in diseased male BXSB mice (24). It was also previously reported that $T$ cells derived from female BXSB mice can support the autoantibody production from $B$ cells of male BXSB mice, thus suggesting a B cell abnormality (2). However, since Lawson et al. also pointed out that less than $1 \times 10^{6}$ cells were sufficient to induce the disease in these $\mathrm{T}$ cell deficient BXSB mice (8), a small number of quiescent intermediate TCR cells is thus suggested to increase in the influence of the Yaa gene in male BXSB mice and may also play some role in tissue damage.

On the other hand, human IL-1 gene transgenic mice spontaneously develop arthritis which resembles human rheumatoid arthritis as early as at 2 weeks of age despite the fact that $\mathrm{T}$ cells and $\mathrm{B}$ cells are only rarely found in articular tissues (10), thus suggesting that macrophage-derived synoviocytes but not $T$ cells or $B$ cells may play an essential role in inducing the disease in these mice. These findings suggest that $\mathrm{T}$ cells, $\mathrm{B}$ cells and macrophages are to various extents involved in autoimmune diseases dependent upon the types of the diseases.

Consistent with our previous findings (24), the decreased NK activity of liver MNC by TM $\beta 1 \mathrm{Ab}$ treatment indicated that NK activity of liver MNC was played by $\mathrm{CD} 4^{+} \mathrm{CD} 122^{+} \mathrm{T}$ cells. Although cytotoxic $\mathrm{CD} 4^{+} \mathrm{T}$ cell clones have been reported, no cytotoxic $\mathrm{CD} 4^{+} \mathrm{T}$ cell population has been reported in mice except for NK1.1 ${ }^{+} \mathrm{T}$ cells (17). However, we previously reported in humans that $\mathrm{CD}^{+} \mathrm{CD} 56^{+}$ cytotoxic $T$ cells could be induced by a culture of peripheral blood lymphocytes with IL-2 and IL-12 (13). It is therefore possible that a small population of such $\mathrm{CD} 4^{+} \mathrm{T}$ cells expand in male BXSB mice due to the influence of the Yaa gene.

Collectively, $\mathrm{CD} 4^{+} \mathrm{CD} 122^{+} \mathrm{T}$ cells which increased in male BXSB mice are considered to be responsible for the mononuclear cell infiltration observed in the liver/kidneys and Th1 dominant state, however, they do not play a major role in the production of either Ig or anti-DNA $\mathrm{Ab}$.

\section{REFERENCES}

1. Chu E. B., Emst D. N., Hobbs M. V. and Weigle W. O. (1994) Maturational changes in CD4+ cell subsets and lymphokine production in BXSB mice. $J$. Immunol. 152, 41294138.

2. Fossati L., Sobel E. S., Iwamoto M., Cohen P. L., Eisenberg R. A. and Izui S. (1995) The Yaa gene-mediated acceleration of murine lupus: Yaa- T cells from non-autoimmune mice collaborate with Yaa+ B cells to produce Iupus autoantibodies in vivo. Eur. J. Immtmol. 25, 3412-3417.

3. Hudgins C. C., Steinberg R. T., Klinman D. M., Reeves M. J. and Steinberg A. D. (1985) Studies of consomic mice bearing the Y chromosome of the BXSB mouse. J. Immunol. 134, 3849-3854.

4. Izui S., Iwamoto M., Fossati L., Merino R., Takahashi S. and Ibnou-Zekri N. (1995) The Ya gene model of systemic lupus erythematosus. Immunol. Rev. 144, 137-156.

5. Jacob C. O., van der Meide P. H. and McDevitt H. O. (1987) In vivo treatment of (NZB X NZW) F1 lupus-like nephritis with monoclonal antibody to gamma interferon. J. Exp. Med. 166, 798-803.

6. Kono D. H., Balomenos D., Park M. S. and Theofilopoulos A. N. (2000) Development of lupus in BXSB mice is independent of IL-4. J. Immmol. 164, 38-42.

7. Lantz O. and Bendelac A. (1994) An invariant T cell receptor alpha chain is used by a unique subset of major histocompatibility complex class I-specific CD4+ and CD4-8- T cells in mice and humans. J. Exp. Med. 180, 1097-1106.

8. Lawson B. R., Koundouris S. I., Barnhouse M., Dummer W., Baccala R., Kono D. H. and Theofilopoulos A. N. (2001) The role of alpha beta+ $\mathrm{T}$ cells and homeostatic $\mathrm{T}$ cell proliferation in Y-chromosome-associated murine lupus. $J$. Immnol. 167, 2354-2360.

9. Nakajima A., Hirose S., Yagita H. and Okumura K. (1997) Roles of IL-4 and IL-12 in the development of lupus in NZB/W F1 mice. J. Immunol. 158, 1466-1472. 
10. Niki Y., Yamada II., Seki S., Kikuchi T., Takaishi H., Toyama Y., Fujikawa K. and Tada N. (2001) Macrophageand neutrophil-dominant arthritis in human IL-1 alpha transgenic mice. J. Clin. Invest. 107, 1127-1135.

11. Ozmen L., Roman D., Fountoulakis M., Schmid G., Ryffel B. and Garotta G. (1995) Experimental therapy of systemic litpus erythematosus: the treatment of NZB/N mice with mouse soluble interferon-gamma receptor inhibits the onset of glomerulonephritis. Eur: J. Immunol. 25, 6-12.

12. Prud'homme G. J., Kono D. H. and Theofilopoulos A. N. (1995) Quantitative polymerase chain reaction analysis reveals marked overexpression of interleukin-1 beta, interleukin-1 and interferon-gamma mRNA in the lymph nodes of lupus-prone mice. Mol. Immunol. 32, 495-503.

13. Satoh M., Seki S., Hashimoto W., Ogasawara K., Kobayashi T., Kumagai K., Matsuno S. and Takeda K. (1996) Cytotoxic gammadelta or alphabeta $\mathrm{T}$ cells with a natural killer cell marker, CD56, induced from human peripheral blood lymphocytes by a combination of IL-12 and IL-2. J. Immunol. 157, 3886-3892.

14. Seki S., Abo T., Ohteki T., Sugiura K. and Kumagai K. (1991) Unusual alpha beta-T cells expanded in autoimmune lpr mice are probably a counterpart of normal $T$ cells in the liver. J. Immunol. 147, 1214-1221.

15. Seki S., Habu Y., Kawamura T., Takeda K., Dobashi H., Ohkawa T. and Hiraide H. (2000) The liver as a crucial organ in the first line of host defense: the roles of Kupffer cells, natural killer (NK) cells and NK1.1 Ag+ T cells in T helper $1 \mathrm{im}$ mune responses. Immunol. Rev. 174, 35-46.

16. Shirai A., Conover J. and Klinman D. M. (1995) Increased activation and altered ratio of interferon-gamma: interleukin4 secreting cells in MRL-1pr/lpr mice. Autoimmunity. 21, 107116.

17. Takeda K., Seki S., Ogasawara K., Anzai R., Hashimoto W.,
Sugiura K., Takahashi M., Satoh M. and Kumagai K. (1996) Liver NK $1.1+$ CD4+ alpha beta T cells activated by IL-12 as a major effector in inhibition of experimental tumor metastasis. J. Immunol. 156, 3366-3373.

18. Tanaka T., Tsudo M., Karasuyama H., Kitamura F., Kono T., Hatakeyama M., Taniguchi T. and Miyasaka M. (1991) A novel monoclonal antibody against murine IL-2 receptor betachain. Characterization of receptor expression in normal lymphoid cells and EL- 4 cells. J. Immunol. 147, 2222-2228.

19. Toyabe S., Seki S., Iiai T., Takeda K., Shirai K., Watanabe H., Hiraide H., Uchiyama M. and Abo T. (1997) Requircment of IL-4 and liver NKI+ T cells for concanavalin A-induced hepatic injury in mice. $J$. Immunol. 159, 1537-1542.

20. Tsukahara A., Seki S., Iiai T., Moroda T., Watanabe H., Suzuki S., Tada T., Hiraide H., Hatakeyama K. and Abo T. (1997) Mouse liver T cells: their change with aging and in comparison with peripheral T cells. Hepatology. 26, 301-309.

21. Watanabe H., Miyaji C., Kawachi Y., Iiai T., Ohtsuka K., Iwanage T., Takahashi-Iwanaga $\mathrm{H}$. and Abo T. (1995) Relationships between intermediate TCR cells and NK1.1+ T cells in various immune organs. NK1.1 $\mathrm{T}$ cells are present within a population of intermediate TCR cells. J. Immumol. 155, 2972-2983.

22. Wofsy D. (1986) Administration of monoclonal anti-T cell antibodies retards murine lupus in BXSB mice. J. Immunol. 136, 4554-4560.

23. Wofsy D., Kerger C. E. and Seaman W. E. (1984) Monocytosis in the BXSB model for systemic lupus erythematosus. $J$. Exp. Med. 159, 629-634.

24. Yoshida Y., Seki S., Yamagiwa S., Sugahara S., Habu Y., Hiraide $H$., Asakura $H$. and Abo T. (1999) Expansion of unusual $C D 4+T$ cells with an intermediate $T$ cell receptor intensity in autoimmune BXSB mice and their $\mathrm{T}$ cell receptor repertoire. Biomed. Res. 20, 327-337. 